\title{
COMPARISON OF ROCK SEAWALL AND DUNE FOR STORM DAMAGE REDUCTION
}

\author{
Hyun Dong Kim ${ }^{1}$, Nobuhisa Kobayashi ${ }^{2}$, and Xavier Chávez Cárdenas ${ }^{3}$
}

\begin{abstract}
Four test series consisting of 14 tests and 140 runs (each run lasted $400 \mathrm{~s}$ ) were conducted in a wave flume with a sand beach and a berm in order to compare the effectiveness of a dune and a rock (stone) seawall placed on the foreshore in reducing wave overtopping and sand overwash. The incident irregular waves were kept approximately the same for all the runs. The water level was increased to create dune erosion and crest lowering as well as stone displacement. The dune was effective in eliminating or reducing wave overtopping and overwash in comparison to the corresponding berm with no dune but the narrow dune was destroyed easily as the water level was increased. The stone seawall reduced wave overtopping and overwash even after it was damaged moderately. A stone seawall buried inside a dune was examined in the last test series. The buried seawall functioned like the dune initially and like the seawall after the sand on the seawall was eroded by overtopping waves. The buried seawall combines the aesthetics of the dune and the robustness of the stone seawall.
\end{abstract}

Keywords: Rock seawall; Dune erosion; Storm damage reduction; Stone damage

\section{INTRODUCTION}

Hurricane Sandy made landfall near Atlantic City, New Jersey during spring tide on October 29, 2012. Irish et al. (2013) and Walling et al. (2014) compared the impacts of Hurricane Sandy on Sea Girt, Bay Head, and Mantoloking north of Atlantic City along the New Jersey Coast. The three communities were chosen because of the vast difference in damage within an alongshore distance of $12 \mathrm{~km}$. A wide beach and a large dune protected Sea Girt which suffered the least damage of the three towns. The beach of Bay Head was narrow but a relic rock seawall was buried underneath its dune. The dune was eroded but the 1260-m long seawall reduced damage to the area landward of the seawall. Mantoloking is located on a barrier spit and its narrow dune almost vanished. Three major breaches were formed across the barrier spit. The post-storm surveys show the consequences of the storm, but do not reveal the actual processes of beach and dune erosion with and without a rock seawall. A laboratory experiment was conducted to compare the effectiveness of a dune, a rock seawall, and a dune with a buried seawall in reducing wave overtopping and overwash that may lead to storm damage.

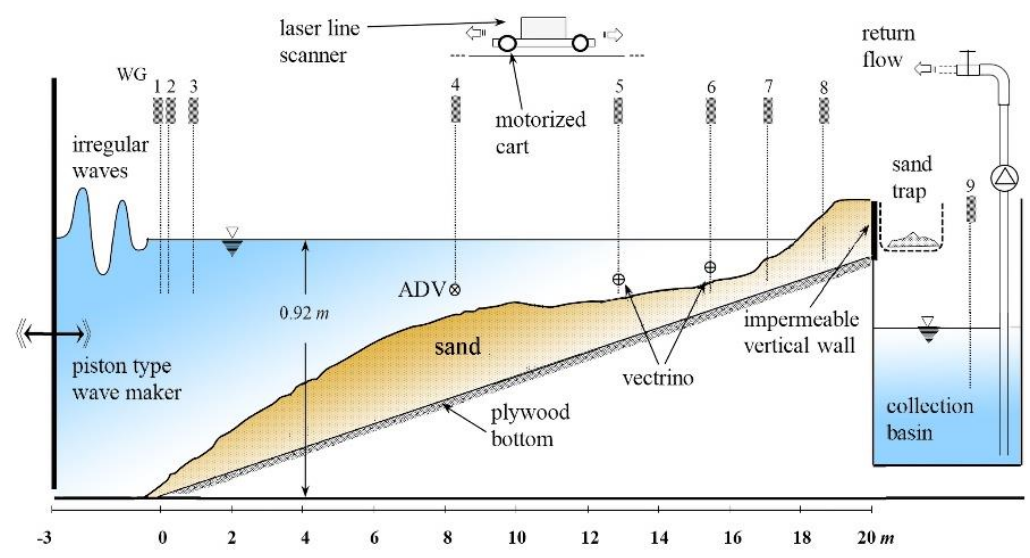

Figure 1: Experimental setup for test NL with no rock seawall and no dune

\footnotetext{
1hdkim@udel.edu, Department of Civil and Environmental Engineering University of Delaware, USA

2 nk@udel.edu, Department of Civil and Environmental Engineering University of Delaware, USA

${ }^{3}$ xaviercc@udel.edu, Department of Civil and Environmental Engineering University of Delaware, USA
} 


\section{EXPERIMENT}

Figure 1 shows the experimental setup in a wave flume that is $30 \mathrm{~m}$ long, $1.15 \mathrm{~m}$ wide and $1.5 \mathrm{~m}$ high. The sand beach in the flume consists of well-sorted fine sand with a median diameter of $0.18 \mathrm{~mm}$. A 400-s run of irregular waves with a TMA spectrum was generated by the piston-type wave maker in a water depth of 92, 94, 96 or $98 \mathrm{~cm}$ corresponding to a low (L), medium (M), high (H), or extreme (E) water level. The spectral significant wave height and peak period were approximately $17 \mathrm{~cm}$ and $2.6 \mathrm{~s}$. Eight wave gauges (WG1 to WG8) were used to measure the free surface elevation outside and inside the surf zone and in the swash zone. The fluid velocities in the surf zone were measured by three velocimeters (one 2D ADV and two Vectrinos) at an elevation of one-third of the local water depth. A vertical wall is located at the onshore coordinate $x=19.9 \mathrm{~m}$ with $x=0$ at WG1. The elevation of the wall crest is $106 \mathrm{~cm}$ above the horizontal flume bottom. The wave overtopping rate $\mathrm{q}_{\mathrm{o}}$ and sand overwash rate $\mathrm{q}_{\mathrm{bs}}$ were measured by collecting overtopped water and sand in a water collection basin and a sand trap during each 400-s run. The beach profile was measured using a laser line scanner system. The three- dimensional bathymetry data were averaged alongshore after confirmation of alongshore uniformity. The experimental setup and data collection were explained in detail by Figlus et al. (2011).

The berm with a foreshore slope of approximately 0.1 shown in Figure 1 corresponds to test NL with no $(\mathrm{N})$ protection by a dune or rock seawall in the water depth of $92 \mathrm{~cm}$. The berm was exposed to ten 400 -s runs in test NL. The water level was raised by $2 \mathrm{~cm}$ and the berm profile at the end of test NL was exposed to 10 runs in test NM. The profile at the end of test NM was exposed to 10 runs in the 96-cm water depth for test NH. The berm was accreted during tests NL and NM and eroded during test NH. The vertical wall was not exposed to direct wave action. Table 1 summaries 4 test series consisting of 14 tests.

Table 1: Sequence of 4 tests series and 14 tests

\begin{tabular}{|c|c|c|c|}
\hline Test & Series & Depth $(\mathrm{cm})$ & No. of runs \\
\hline $\mathrm{NL}$ & \multirow{3}{*}{$\begin{array}{c}\text { No } \\
\text { protection }\end{array}$} & 92 & 10 \\
\hline NM & & 94 & 10 \\
\hline $\mathrm{NH}$ & & 96 & 10 \\
\hline $\mathrm{DL}$ & \multirow{3}{*}{ Dune only } & 92 & 10 \\
\hline $\mathrm{DM}$ & & 94 & 10 \\
\hline $\mathrm{DH}$ & & 96 & 10 \\
\hline $\mathrm{RL}$ & \multirow{4}{*}{$\begin{array}{c}\text { Rock } \\
\text { seawall }\end{array}$} & 92 & 10 \\
\hline RM & & 94 & 10 \\
\hline RH & & 96 & 10 \\
\hline $\mathrm{RE}$ & & 98 & 10 \\
\hline $\mathrm{BL}$ & \multirow{4}{*}{$\begin{array}{c}\text { Buried rock } \\
\text { seawall }\end{array}$} & 92 & 10 \\
\hline $\mathrm{BM}$ & & 94 & 10 \\
\hline $\mathrm{BH}$ & & 96 & 10 \\
\hline $\mathrm{BE}$ & & 98 & 10 \\
\hline
\end{tabular}

For the dune (D) test series, the initial berm profile was rebuilt and sand dune with a crest elevation of $10 \mathrm{~cm}$ above the berm crest was built on the foreshore before test DL as shown in Figure 2. The vertical wall is located at $\mathrm{x}=19.9 \mathrm{~m}$. The vertical coordinate $\mathrm{z}$ is positive upward and $\mathrm{z}=0$ at the still water level (SWL). The cross section area of the dune above the foreshore was $526 \mathrm{~cm}^{2}$. The seaward dune slope was eroded during test DL. The water level increase of $2 \mathrm{~cm}$ resulted in the decrease of the dune crest during test DM. The further SWL increase of $2 \mathrm{~cm}$ caused the destruction of the dune during test DH. 


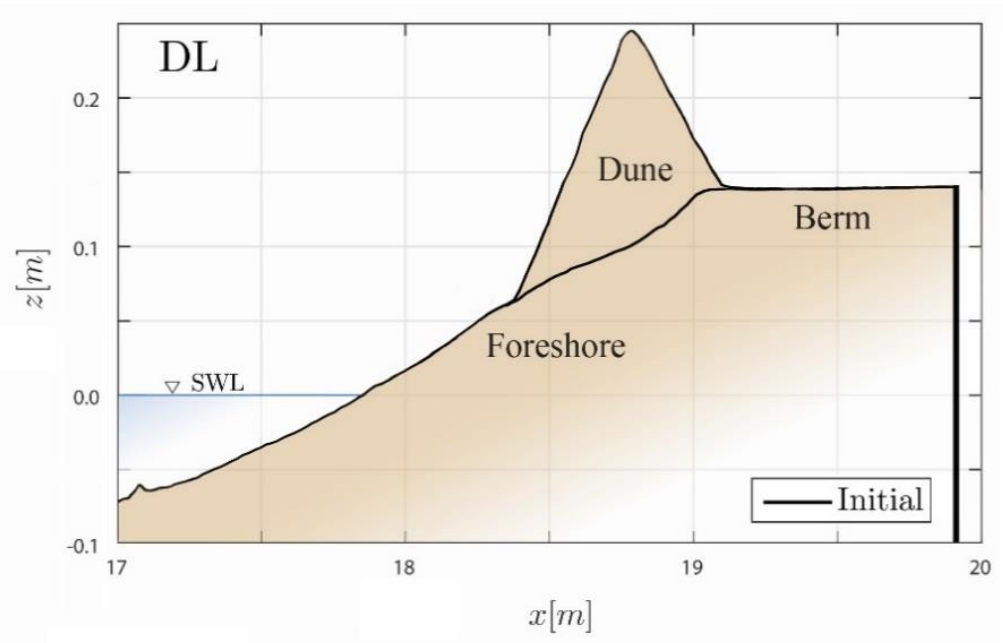

Figure 2: Sand dune built on foreshore before test DL

For the rock (R) seawall test series, the initial berm profile was rebuilt and the profile was measured. A rock (stone) seawall with a crest height of about $8 \mathrm{~cm}$ and a horizontal width of $56 \mathrm{~cm}$ was built on polyester fabric mesh with an opening of $0.074 \mathrm{~mm}$ placed on the rebuilt foreshore (Figure 3 ) before test RL. The cross section area of the seawall was $253 \mathrm{~cm}^{2}$ and the side slopes were about $1 / 2$. During tests RL and RM with the water depth of $92 \mathrm{~cm}$ and $94 \mathrm{~cm}$, respectively, no wave overtopping occurred and the profile change was relatively small. During test RH with the 96-cm water depth, minor wave overtopping occurred and the sand beach was eroded (accreted) seaward (landward) of the seawall. The water depth was increased to $98 \mathrm{~cm}$ so as to increase wave overtopping and overwash significantly.

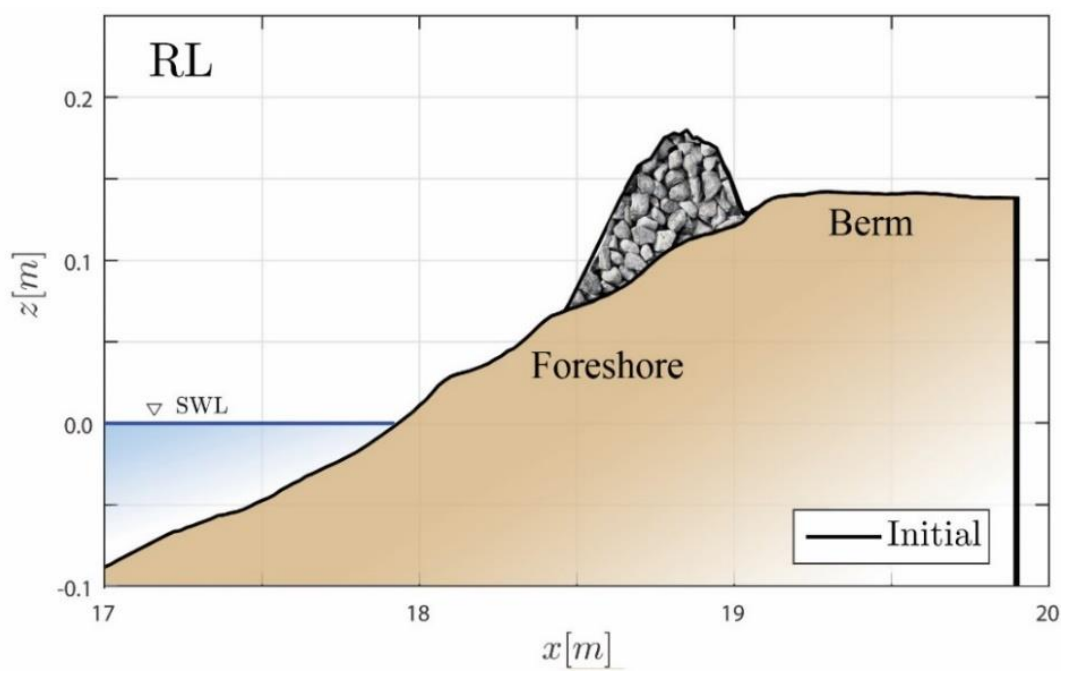

Figure 3: Stone seawall built on foreshore before test RL

For the buried (B) seawall test series, the berm profile was rebuilt and measured. A seawall was built on the rebuilt profile (Figure 4) and the seawall profile was measured. The cross section area of the seawall was $224 \mathrm{~cm}^{2}$ for test BL ( $253 \mathrm{~cm}^{2}$ for test RL). Sand and water mixture was poured into the seawall to fill its voids with sand. A sand dune was built to cover the entire seawall (Figure 5) and the dune profile was measured. The cross section area of the dune including the seawall was $469 \mathrm{~cm}^{2}$ for test BL $\left(527 \mathrm{~cm}^{2}\right.$ for test DL). The buried seawall shown in Figure 5 was exposed to wave action of 10 runs for each of the water depths of $92,94,96$, and $98 \mathrm{~cm}$. 


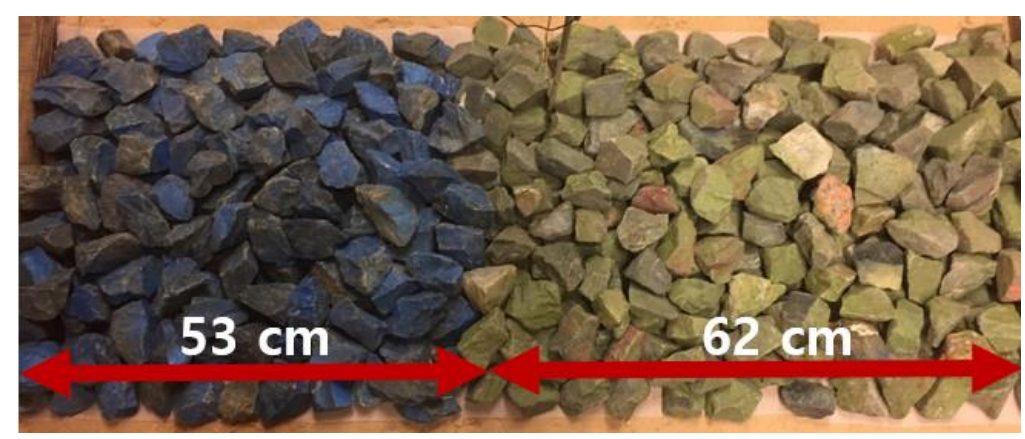

Figure 4: Stone seawall before sand covering for test BL

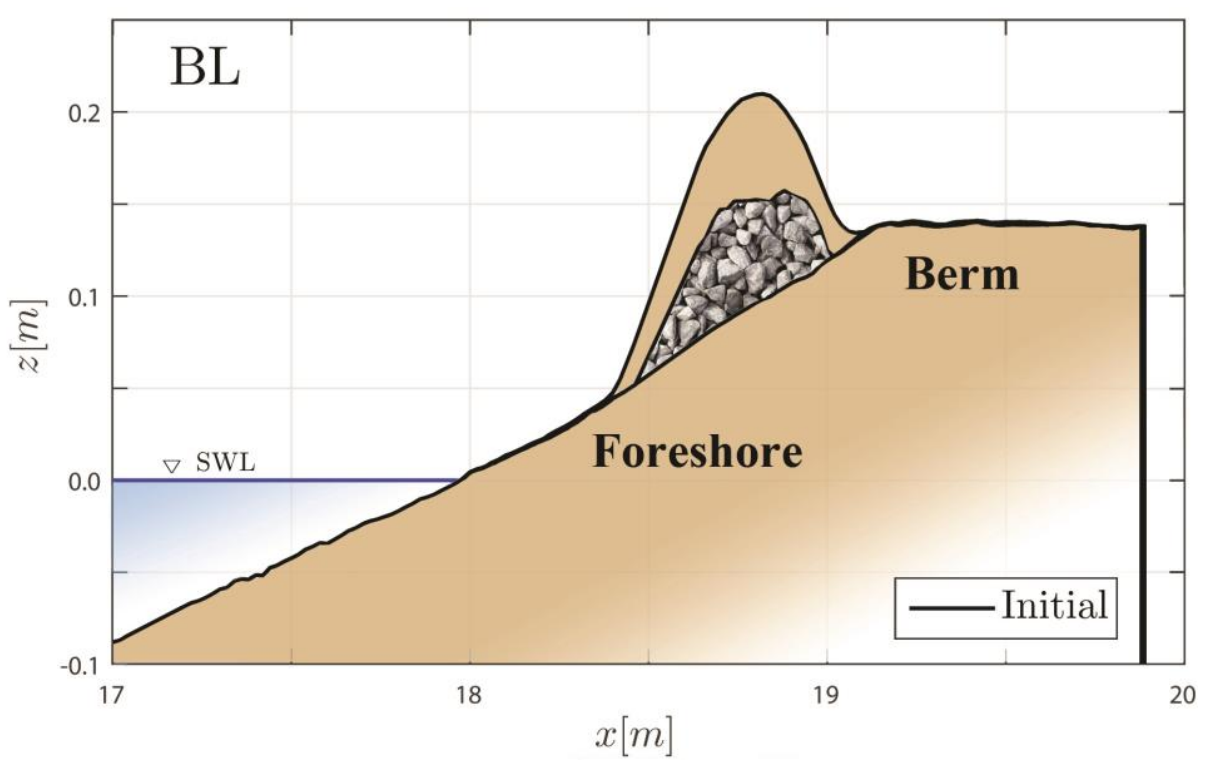

Figure 5: Buried stone seawall built on foreshore before test BL

Table 2: Characteristics of sand and two stones

\begin{tabular}{|c|c|c|c|}
\hline Parameter & Sand & Green Stone & Blue Stone \\
\hline Density $\left(\mathrm{g} / \mathrm{cm}^{3}\right)$ & 2.60 & 2.94 & 3.06 \\
\hline Porosity & 0.40 & 0.44 & 0.44 \\
\hline Diameter $(\mathrm{cm})$ & 0.018 & 3.52 & 3.81 \\
\hline Width $(\mathrm{cm})$ & 115 & 62 & 53 \\
\hline
\end{tabular}

Table 2 lists the characteristics of the sand and two stones used in the experiment. The sand with its median diameter of $0.18 \mathrm{~mm}$ was placed across the $115-\mathrm{cm}$ wide flume. Two different stones colored green and blue were used as shown in Figure 4. These stones were used by Garcia and Kobayashi (2015) who measured damage initiation on a submerged breakwater located inside the surf zone on a sand beach in the same flume. The nominal stone diameters $D_{n 50}=\left(M_{50} / \rho_{s}\right)^{1 / 3}$ of the green and blue stones are 3.52 and $3.81 \mathrm{~cm}$, respectively, where $\mathrm{M}_{50}=$ median stone mass and $\rho_{\mathrm{s}}=$ stone density. It is noted that no formula exists to estimate stone damage initiation on seawalls located on the foreshore in the swash zone. The use of the same stones for similar wave conditions allows the comparison of the stone response in the surf and swash zones. 


\section{WAVE TRANSFORMATION}

The time series from wave gauge WG1 - WG3 located at $\mathrm{x}=0.0,0.25$, and $0.95 \mathrm{~m}$ for each run were used to separate incident and reflected waves at the location $\mathrm{x}=0$ of WG1. The spectral significant wave height $\mathrm{H}_{\mathrm{mo}}$ and peak period $\mathrm{T}_{\mathrm{p}}$ of incident waves were approximately $17 \mathrm{~cm}$ and $2.6 \mathrm{~s}$. The reflection coefficient defined as the ratio between the values of $\mathrm{H}_{\text {mo }}$ for the reflected and incident waves was about 0.2. The analyzed data for 10 runs in test RH are presented in Figure 6 as an example.

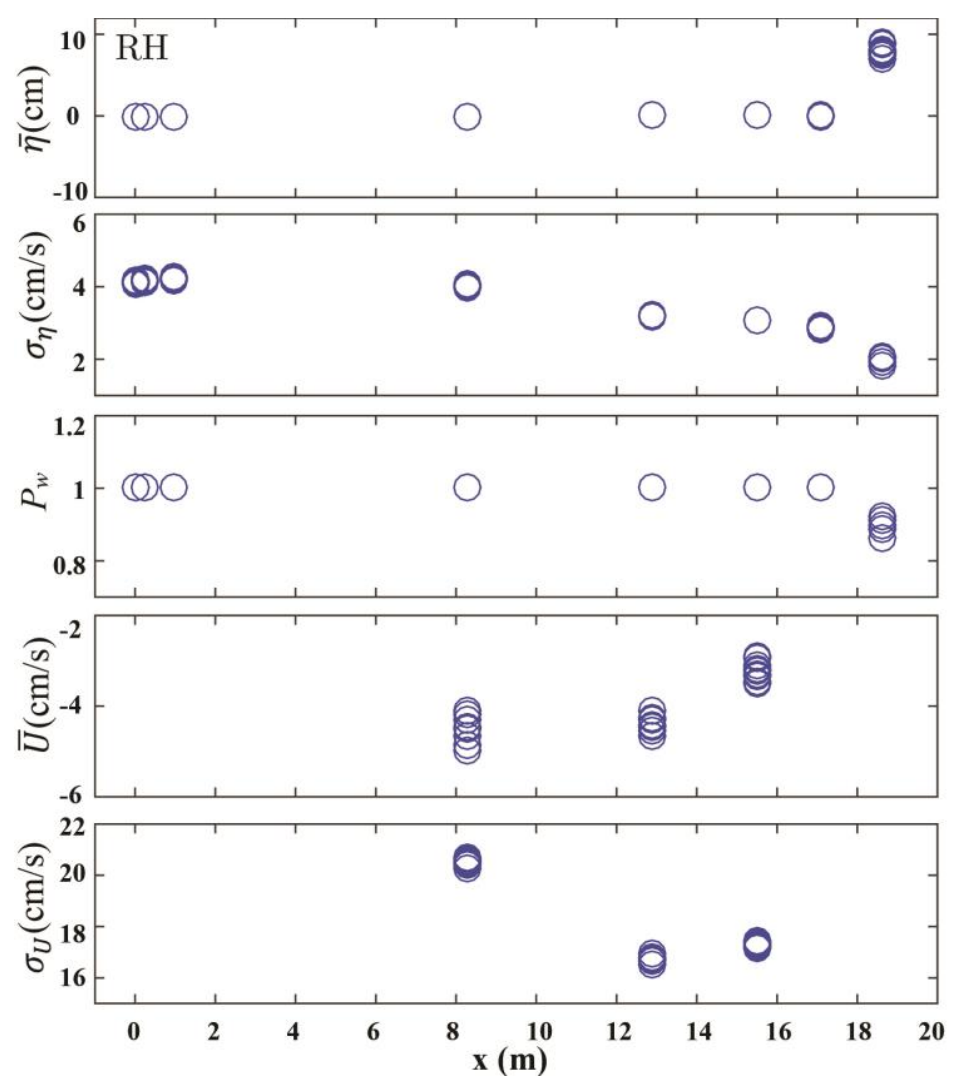

Figure 6: Mean and standard deviation of free surface elevation $\eta$ and horizontal velocity $U$ together with wet probability $P_{w}$ for 10 runs in test $R H$

The mean $\bar{\eta}$ and standard deviation (SD) $\sigma_{\eta}$ of the free surface elevation $\eta$ above SWL at the eight wave gauges for each run were calculated to examine the cross-shore wave transformation. The measured values of $\bar{\eta}$ were negative (wave setdown) at WG1 - WG3 outside the surf zone and WG4 at $\mathrm{x}=$ $8.3 \mathrm{~m}$ near the breaker zone. The values of $\bar{\eta}$ were positive (wave setup) at WG5 - WG7 at $\mathrm{x}=12.9,15.5$, and $17.1 \mathrm{~m}$ in the inner surf zone. The value $\bar{\eta}$ of WG8 at $\mathrm{x}=18.6 \mathrm{~m}$ in the swash zone was affected by the bottom elevation change at WG8. The averaging for WG8 buried partially in the sand above SWL was performed for the wet duration only. The cross-shore variation of the local significant wave height $\mathrm{H}_{\mathrm{mo}}=4$ $\sigma_{\eta}$ was related to the wave height decay due to irregular wave breaking. The wet probability $P_{w}$ defined as the ratio between the wet and total duration was $\mathrm{P}_{\mathrm{w}}=1.0$ at WG1 - WG7. The value of $\mathrm{P}_{\mathrm{w}}$ at WG8 in the swash zone increased with the increase of SWL by the 2 -cm increment in each test series. The mean $\bar{U}$ and 
SD $\sigma_{U}$ of the measured cross-shore velocity $\mathrm{U}$ at $\mathrm{x}=8.3,12.9$, and $15.5 \mathrm{~m}$ are also presented in Figure 6 . The measured alongshore and vertical velocities were small in comparison with the cross-shore velocity in this experiment. The mean horizontal velocity $\bar{U}$ was negative because of the wave-induced offshore return current. The SD $\sigma_{U}$ is related to the wave-induced oscillatory velocity. The return current and oscillatory velocity decreased from the breaker zone to the inner surf zone. The values of $\bar{U}$ of the order of $-4 \mathrm{~cm} / \mathrm{s}$ were harder to measure accurately than those of $\sigma_{U}$ of the order of $20 \mathrm{~cm} / \mathrm{s}$. The cross-shore wave transformation in the shoaling and surf zones was similar for all the runs because the beach profile in these zones was approximately in equilibrium under the specified incident waves.

\section{WAVE OVERTOPPING AND OVERWASH}
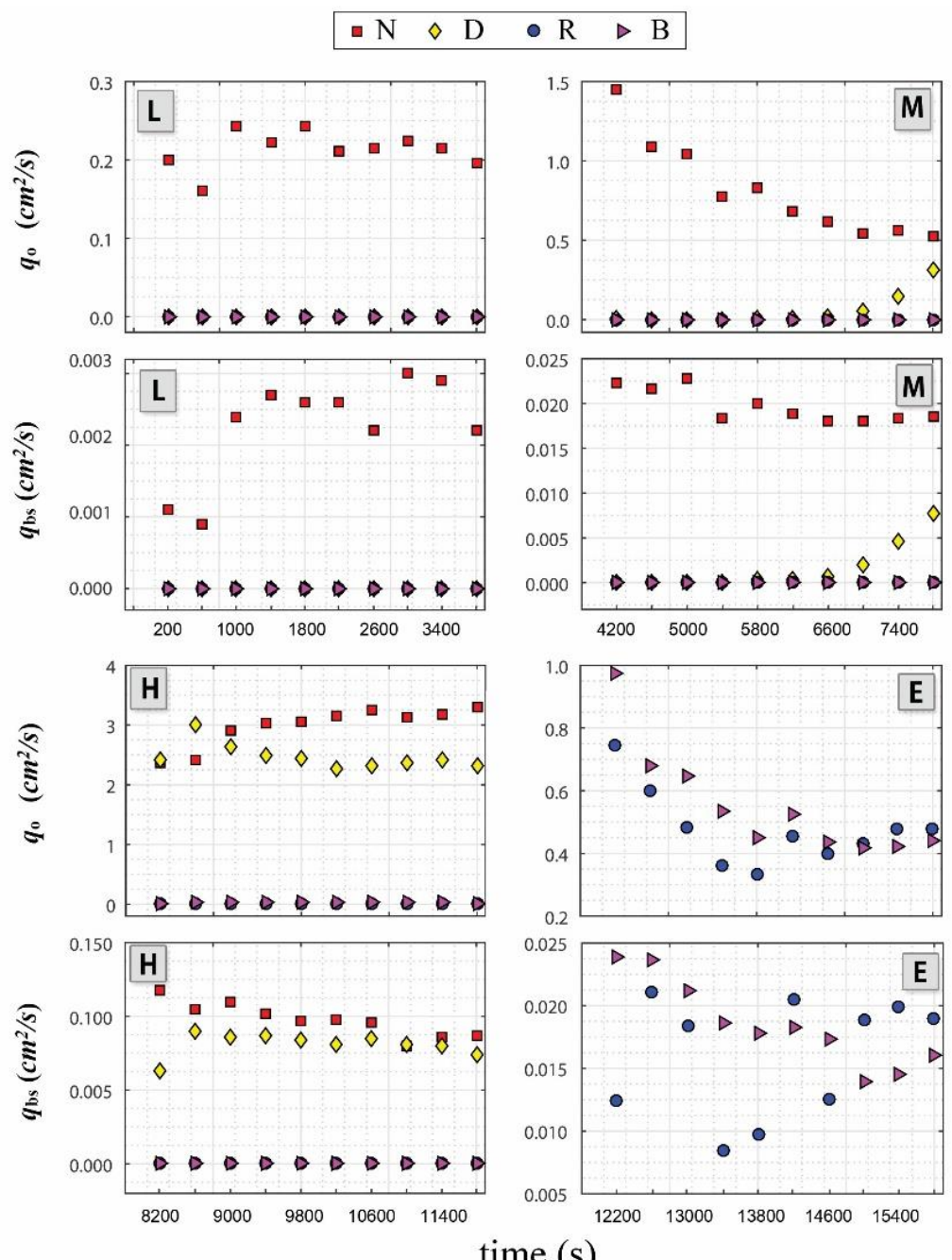

Figure 7: Temporal variations of wave overtopping rate $q_{o}$ and sand overwash rate $q_{b s}$ for $N$ (no), D (dune), R (rock), and B (buried) test series with $2 \mathrm{~cm}$ SWL increase at time $t=4000$, 8000 , and $12000 \mathrm{~s}$ 
The volumes of water and sand transported over the impermeable vertical wall were used to obtain the water overtopping rate $\mathrm{q}_{\mathrm{o}}$ and sand overwash rate $\mathrm{q}_{\mathrm{bs}}$ per unit width averaged over each 400 -s run. Figure 7 shows the temporal variations of $\mathrm{q}_{\mathrm{o}}$ and $\mathrm{q}_{\mathrm{bs}}$ for all the runs in each of the four test series. The average rates are plotted at time $\mathrm{t}$ corresponding to the middle of each run where $\mathrm{t}=0$ at the start of each test series and the water depth was increased by the $2 \mathrm{~cm}$ increment at $\mathrm{t}=4000,8000$, and $12000 \mathrm{~s}$. The overtopping rate and overwash rate did not change much during each test with constant SWL but increased significantly with the increase of SWL. The height of the vertical wall crest above SWL was 14, 12, 10, and $8 \mathrm{~cm}$ for the L, $\mathrm{M}, \mathrm{H}$, and $\mathrm{E}$ tests, respectively. The measured values of $\mathrm{q}_{\mathrm{o}}$ and $\mathrm{q}_{\mathrm{bs}}$ for the given SWL were different among the N, D, R, and B test series. The dune (D) prevented wave overtopping and overwash during test DL but the values of $\mathrm{q}_{\mathrm{o}}$ and $\mathrm{q}_{\mathrm{bs}}$ became similar to those for the berm with no $(\mathrm{N})$ dune after the dune crest was lowered and destroyed during test $\mathrm{DH}$. The rock $(\mathrm{R})$ seawall prevented wave overtopping and overwash during tests RL and RM and reduced $\mathrm{q}_{\mathrm{o}}$ and $\mathrm{q}_{\mathrm{bs}}$ significantly during test $\mathrm{RH}$ in comparison to tests $\mathrm{NH}$ and $\mathrm{DH}$. The values of $\mathrm{q}_{\mathrm{o}}$ and $\mathrm{q}_{\mathrm{bs}}$ during test RE were still smaller than those for tests $\mathrm{NH}$ and $\mathrm{DH}$. The buried (B) seawall also prevented wave overtopping and overwash during tests BL and BM. The values of $\mathrm{q}_{\mathrm{o}}$ and $\mathrm{q}_{\mathrm{bs}}$ for tests $\mathrm{BH}$ and $\mathrm{BE}$ of the sand-filled seawall were larger than those for tests RH and RE because of the reduced roughness and sand in the stone voids. The difference between tests BE and RE diminished after sand was removed from the stone seawall.

\section{PROFILE CHANGES}

Figure 8 shows the initial, intermediate, and final profiles for tests NL, NM, and NH where the vertical coordinate $\mathrm{z}$ is positive upward with $\mathrm{z}=0$ at $\mathrm{SWL}$. Each profile is identified by its run number starting from run number 0 for the initial profile. The run number is affixed to the test name. The profiles in the zone of $\mathrm{x}=16-19.9 \mathrm{~m}$ of noticeable profile changes are presented for clarity. The foreshore slope was eroded and became slightly steeper during test NL. The eroded sand was deposited on the berm and transported over the vertical wall located at $\mathrm{x}=19.9 \mathrm{~m}$. A sediment budget analysis for the zone of $\mathrm{x}=16$ $-19.9 \mathrm{~m}$ indicated that some of the eroded sand was also dispersed offshore from $\mathrm{x}=16 \mathrm{~m}$. However, the deposited sand was not detectable from the profile measurement of 1-mm uncertainty. After the 2-cm increase of SWL in test NM, the trend of foreshore erosion and berm accretion continued. The additional 2-cm increase of SWL in test NH caused the upward increase of foreshore erosion with no berm accretion, which resulted in the foreshore slope decrease. The profile evolution differences among tests NL, NM, and $\mathrm{NH}$ may be related to the different rates of $\mathrm{q}_{\mathrm{o}}$ and $\mathrm{q}_{\mathrm{bs}}$ shown in Figure 7. The values of $\mathrm{q}_{\mathrm{o}}$ and $\mathrm{q}_{\mathrm{bs}}$ did not change much in spite of the temporal change of the berm elevation during each test. This may be explained by the increase (decrease) of the foreshore slope coupled with the increase (decrease) of the berm elevation in tests $\mathrm{NL}$ and $\mathrm{NM}(\mathrm{NH})$. 


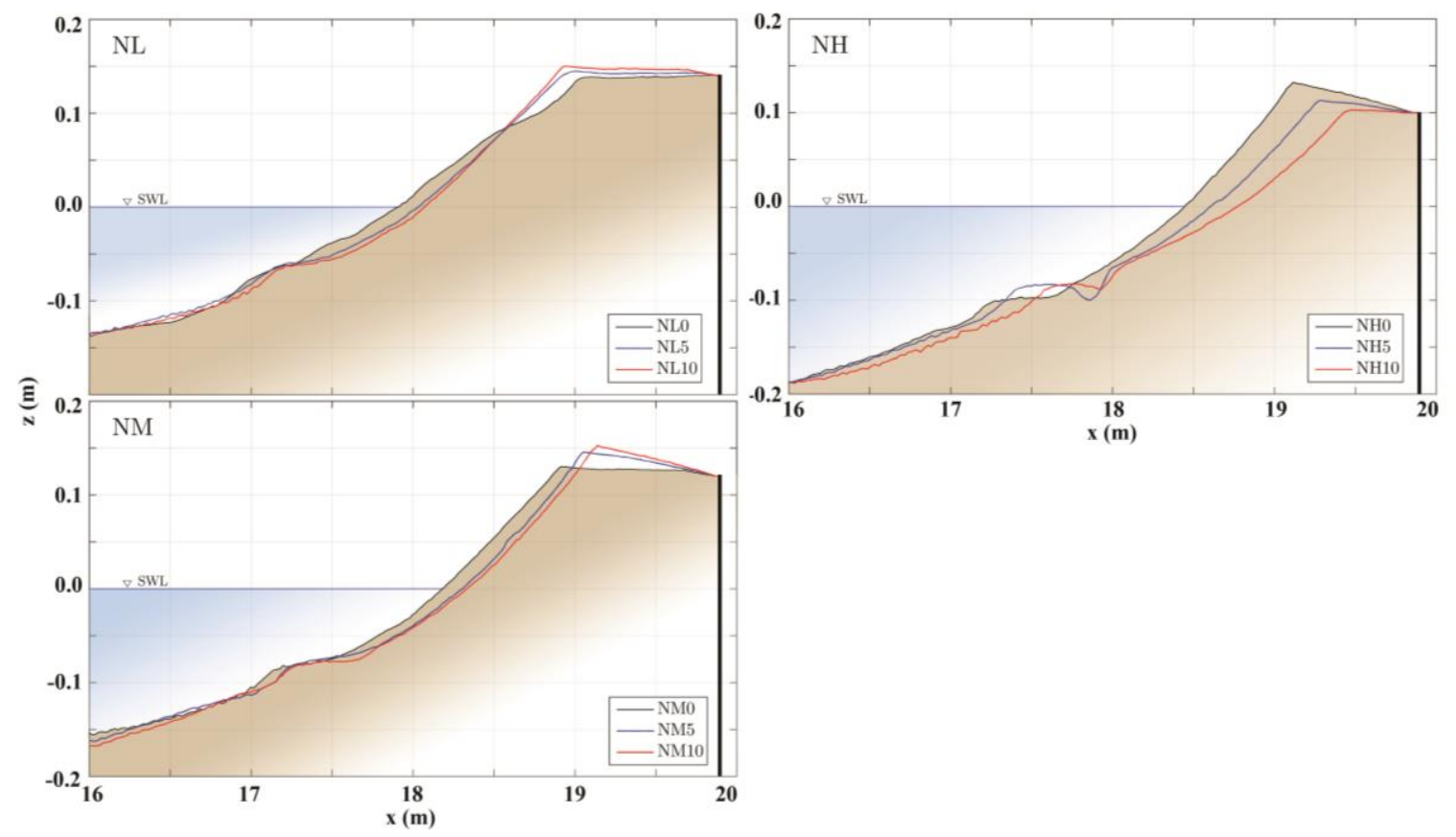

Figure 8: Initial (0), intermediate (5) and final (10) profiles for tests NL (low water level), NM (medium), and NH (high)

The profile evolution of the dune (D) test series is shown in Figure 9. The seaward dune slope was eroded but appeared to have become fairly stable during test DL of no wave overtopping. The 2-cm increase of SWL in test DM initiated wave overtopping and overwash resulting in the rapid lowering of the dune crest. Some of the overwashed sand was deposited on the berm. The 2-cm SWL increase at the start of test DH increased wave overtopping and sand overwash, as shown in Figure 7. The dune crest was destroyed and the foreshore was eroded in the same manner as in test $\mathrm{NH}$ (Figure 8). The narrow dune is vulnerable and its effectiveness is essentially limited to the condition of no wave overtopping.

Figure 10 shows the measured profiles for tests RL, RM, RH, and RE. The profile measurements were conducted at the beginning of test RL and at the end of each of the four tests because of the relatively slow profile evolution. During test RL, onshore sand transport resulted in slight sand deposition in the vicinity of the seawall toe. The 2-cm SWL increase in test RM caused slight foreshore erosion and slight sand deposition on the berm landward of the seawall. No wave overtopping of the vertical wall occurred during test RM but wave uprush penetrated through the porous seawall and deposited sand. The trend of foreshore erosion and berm accretion continued during test RH with $\mathrm{q}_{\mathrm{o}}$ and $\mathrm{q}_{\mathrm{bs}}$ of the order of $10^{-2}$ and $10^{-5}$ $\mathrm{cm}^{2} / \mathrm{s}$, respectively. The increase of $\mathrm{q}_{\mathrm{o}}$ and $\mathrm{q}_{\mathrm{bs}}$ to the order of 0.5 and $0.02 \mathrm{~cm}^{2} / \mathrm{s}$ during test $\mathrm{RE}$ created a scour trench landward of the seawall. The seaward slope and crest of the seawall were eroded during tests RH and RE. The measured stone damage is analyzed in the next section.

The profile evolution of the buried (B) seawall test series is shown in Figure 11. The seaward dune slope erosion during test BL of no wave overtopping was similar to that of test DL in Figure 9. The upper seaward slope of the stone seawall was exposed at the end of test BL (Figure 12). This uncovered seawall appears similar to the uncovered relic seawall at Bay Head after Hurricane Sandy (Irish et al. 2013). The dune slope erosion continued with little dune crest lowering during test BM of no wave overtopping. The 
exposed seawall reduced dune erosion in comparison to the rapid crest lowering of the dune with no seawall in test DM in Figure 9. The dune was destroyed during test BH with $\mathrm{q}_{\mathrm{o}}$ and $\mathrm{q}_{\mathrm{bs}}$ of the order of 0.02 and 10${ }^{4} \mathrm{~cm}^{2} / \mathrm{s}$, respectively, for test $\mathrm{BH}$. The overtopping and overwash rates were larger for test $\mathrm{BH}$ than test $\mathrm{RH}$ with no sand on the seawall. After the sand cover was removed in test BE, the profile change became similar to that of test RE. It is noted that the four wooden blocks on the berm (Figure 12) were dry, wet and slid slightly for no, minor and major wave overtopping, respectively.

After tests RE and BE, the stones were removed carefully in order to measure sand deposited or remaining on the fabric mesh using the procedure adopted by Garcia and Kobayashi (2015) who conducted an experiment for a submerged breakwater in the surf zone on a sand beach using the same sand and stones in the present wave flume. The height of loose sand on the fabric mesh was measured using the laser line scanner. The sand mass was also measured to estimate the porosity of the loose sand, which was approximately 0.58 . The loose sand height was converted to the beach sand height whose porosity was 0.4. The average sand height on the fabric mesh was 0.6 and $1.0 \mathrm{~mm}$ after tests $\mathrm{RE}$ and $\mathrm{BE}$, respectively. The sand poured into the stone voids before test BL was removed almost completely by wave action in the swash zone. Garcia and Kobayashi (2015) observed sand deposition of about $2 \mathrm{~mm}$ inside a stone breakwater that was geometrically similar to the seawall built before test RL. The erosion and deposition mechanisms of sand in a porous structure are poorly understood at present.

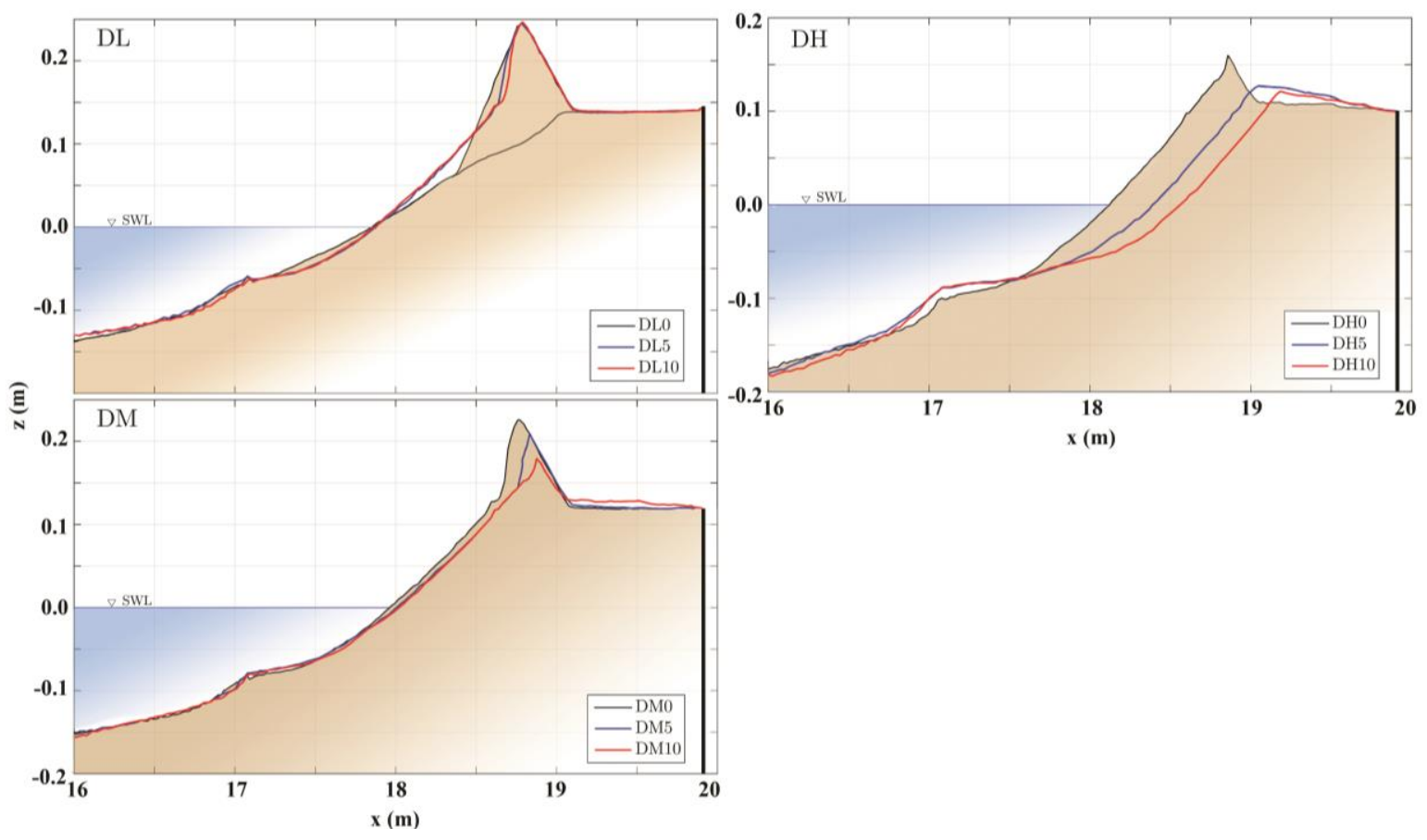

Figure 9: Initial (0), intermediate (5) and final (10) profiles for tests DL, DM, and DH 


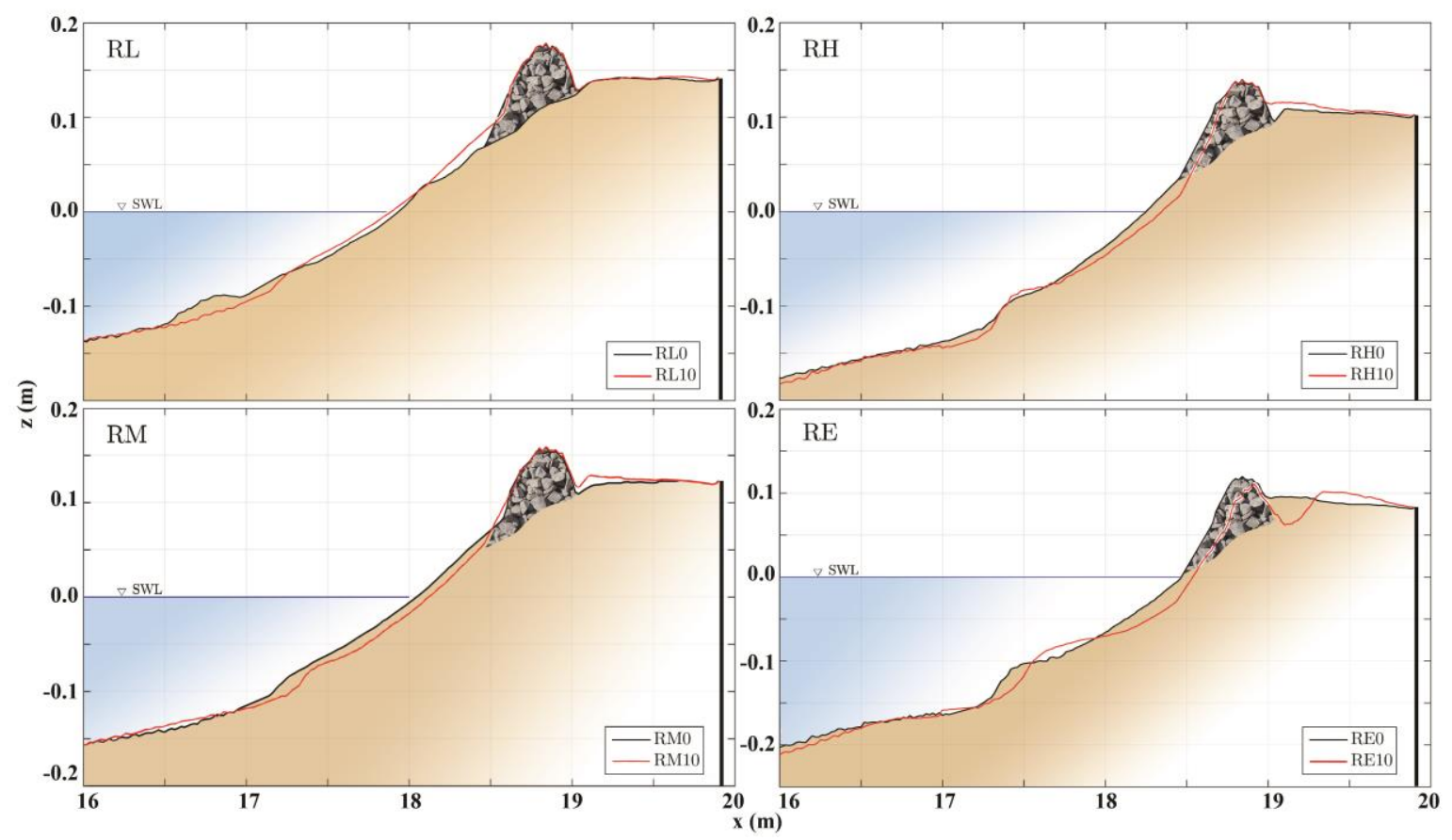

Figure 10: Initial (0), and final (10) profiles for tests RL, RM, RH, and RE (extreme water level) where initial stone cross section is indicated in each panel

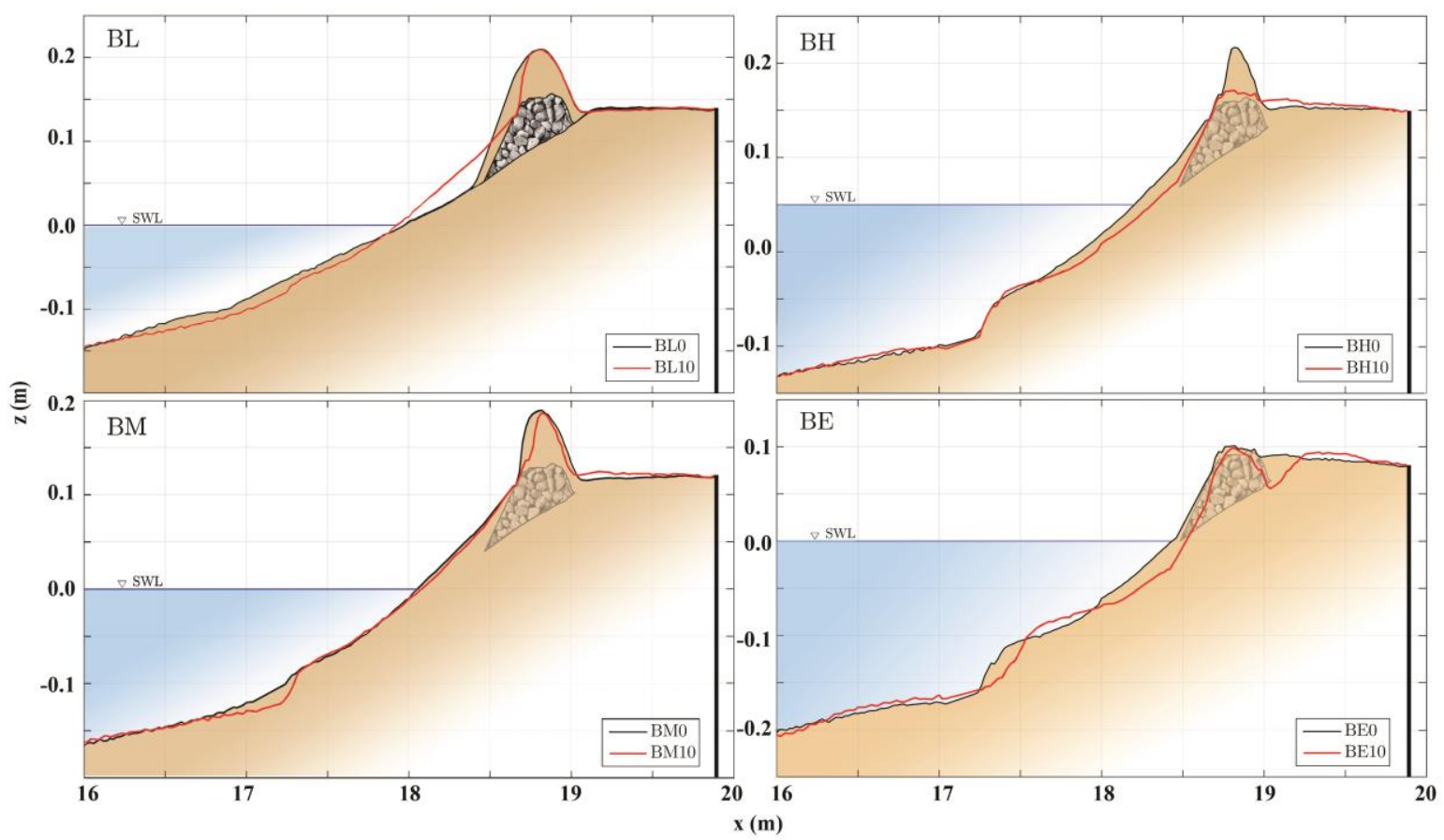

Figure 11: Initial (0), and final (10) profiles for tests BL, BM, BH, and BE (extreme water level) where initial stone cross section is indicated in each panel 


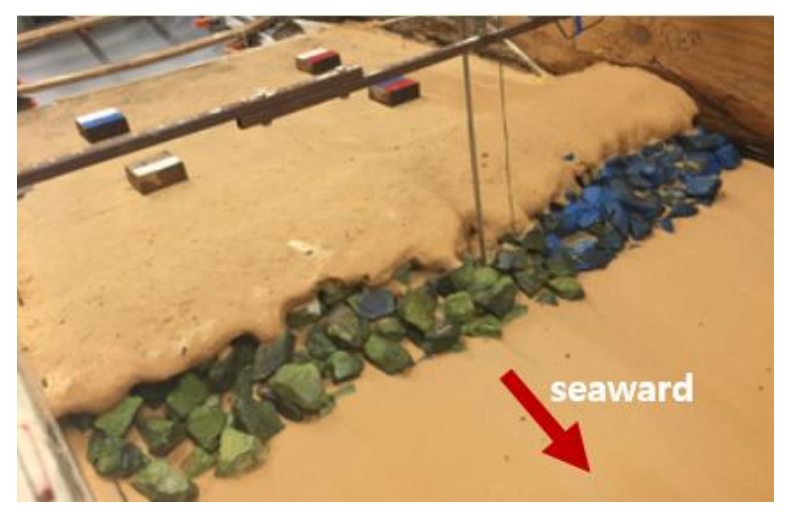

Figure 12: Exposed stone due to dune erosion after test BL where 4 wooden blocks were placed on berm

\section{STONE DAMAGE}

Damage progression of the stone seawall is analyzed for the $\mathrm{R}$ and $\mathrm{B}$ test series (Figure 10 and 11). The eroded area $A_{e}$ of the initial stone cross section in the zone of $x=18.46-19.02 \mathrm{~m}$ is calculated at the end of each of the four tests $(t=4000,8000,12000$, and $16000 \mathrm{~s})$. The segments of the green and blue stones (Figure 4) are analyzed separately using the alongshore averaged profiles for each segment. Figure 13 shows the temporal variation of damage $S=\mathrm{A}_{\mathrm{e}} /\left(\mathrm{D}_{\mathrm{n} 50}\right)^{2}$ where $\mathrm{D}_{\mathrm{n} 50}=3.52$ and $3.81 \mathrm{~cm}$ for the green and blue stones (Table 2) and $S=0$ at $\mathrm{t}=0$. The green stone damage was slightly larger than the blue stone damage as expected from the $8 \%$ difference of the nominal diameters. The damage $S$ at the given time was larger for the $\mathrm{R}$ test series because of the sand cover protection. The incident significant wave height $\mathrm{H}_{\mathrm{mo}}$ at $\mathrm{x}=0$ was approximately $17 \mathrm{~cm}$ for all the test series. The stability number $N_{s}=\mathrm{H}_{\mathrm{mo}} /\left[\left(\rho_{s} / \rho-1\right) \mathrm{D}_{\mathrm{n} 50}\right]$ with $\rho=$ water density $\left(1 \mathrm{~g} / \mathrm{cm}^{3}\right)$ and $\rho_{s}=$ stone density (Table 2$)$ is 2.5 and 2.2 for the green and blue stones if $\mathrm{H}_{\mathrm{mo}}=17 \mathrm{~cm}$ at $\mathrm{x}=0$ is used in $N_{s}$. However, the offshore wave height is inadequate in predicting the stone damage in the swash zone. The intensity of wave uprush and downrush increased with the 2-cm SWL increase at $\mathrm{t}=4000,8000$, and $12000 \mathrm{~s}$ and the increased intensity caused the increase of the damage in Figure 13.

Stone damage in Figure 13 may have been caused mostly by sand undermining below the fabric mesh and stone settlement because stone movement was observed to be very small. Figure 14 shows the initial and final profiles for the $\mathrm{R}$ and $\mathrm{B}$ test series. The elevation corresponds to the $\mathrm{z}$ coordinate of the initial profiles in Figures 10 and 11. The toe of the stone seawall was exposed to wave action and sand was washed away below the seawall at the end of the R and B test series. Sand undermining appears to have increased significantly during test RE in Figure 14, resulting in the large damage at the end of the R test series in Figure 13. 


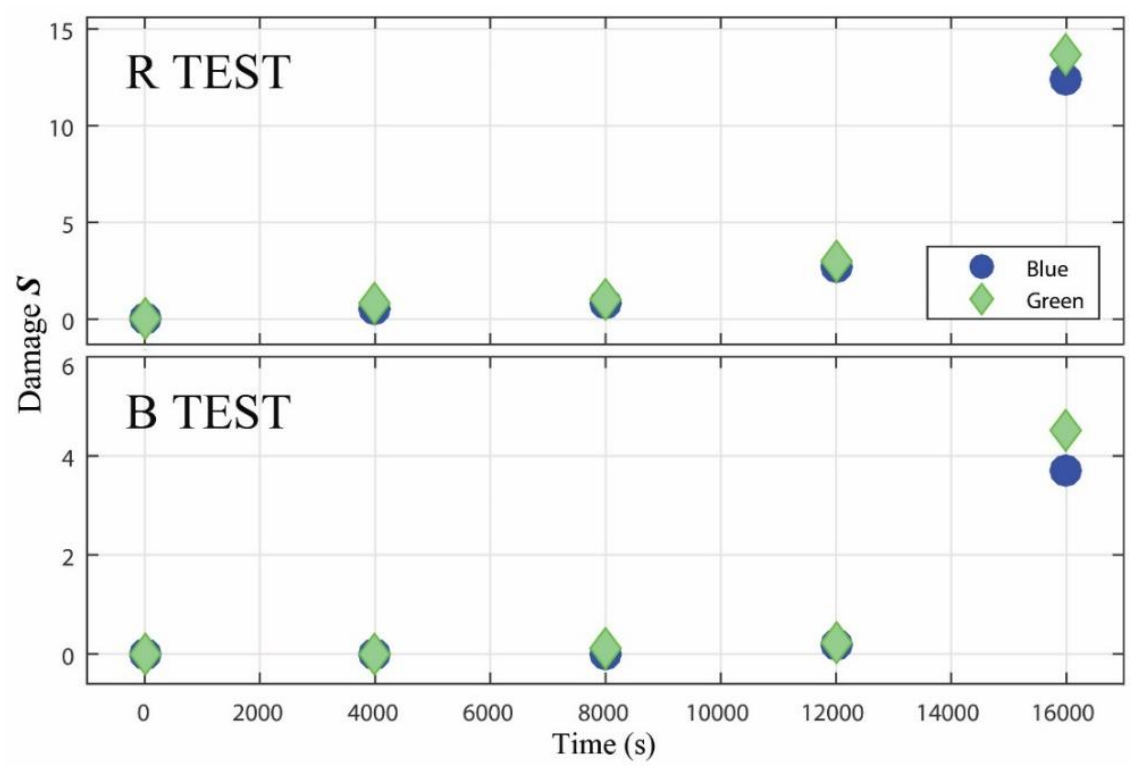

Figure 13: Damage progression of green and blue stones in $R$ and $B$ test series

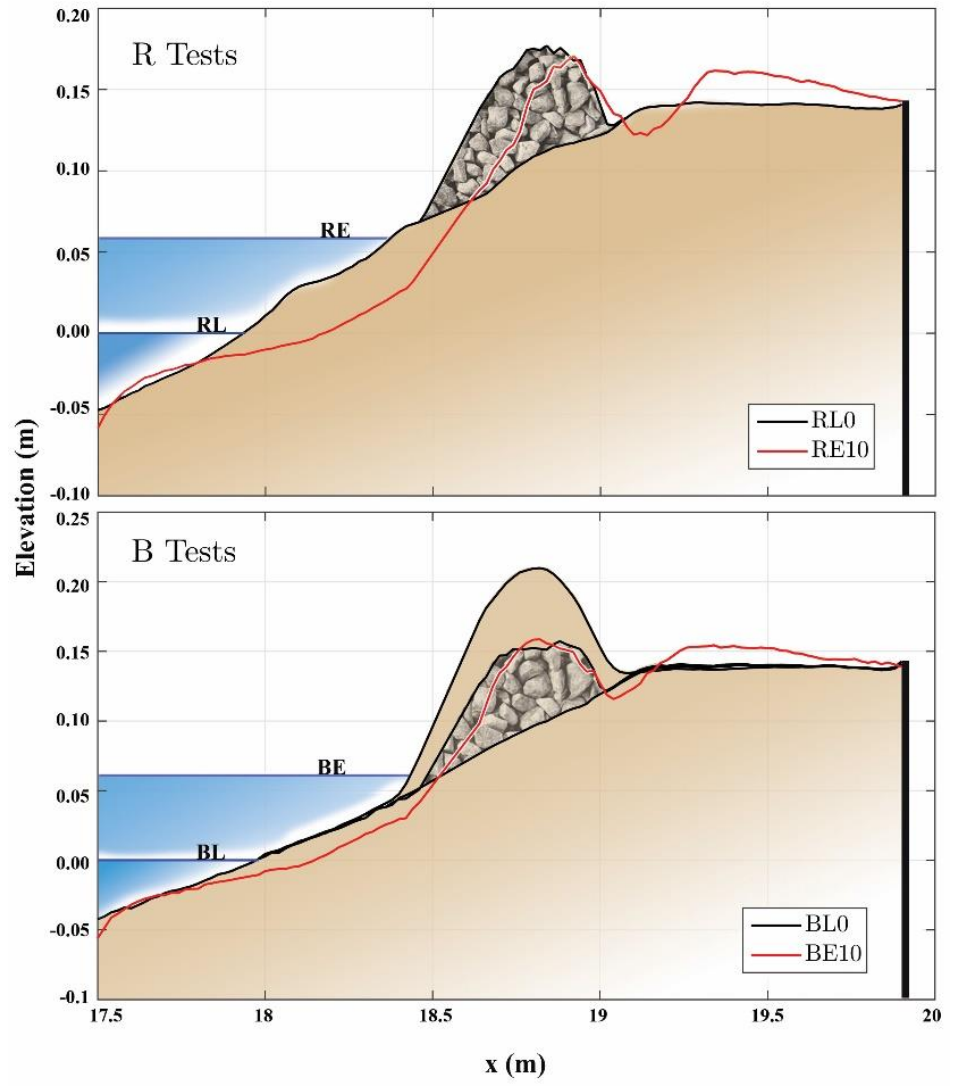

Figure 14: Initial (RLO and BLO) and final (RE10 and BE10) profiles for R and B test series 


\section{CONCLUSIONS}

Four test series consisting of 14 tests and 140 runs were conducted in a wave flume with a sand beach and a berm in order to compare the effectiveness of a dune, a stone seawall, and a seawall buried inside a dune on the foreshore in reducing wave overtopping and sand overwash of the berm. The incident irregular waves were kept approximately the same for all the runs. The water level was increased with an increment of $2 \mathrm{~cm}$. The effectiveness of the narrow dune is found to be limited to the condition of no wave overtopping and its vulnerability is large. The stone seawall was effective in reducing wave overtopping and ovewash even after it was damaged moderately. The sand cover of the buried seawall acted like the narrow dune before it was removed by swash action. The exposed seawall behaved like the seawall with no sand cover. The sand cover reduced the roughness and porosity of the seawall, resulting in the increased overtopping and overwash, but it protected the stone seawall against swash action. A numerical model will be developed to generalize the findings of these limited small-scale tests.

\section{ACKNOWLEDGEMENTS}

This study was partially supported by the U.S. Army Corps of Engineers under Cooperative Agreement No. W912HZ-15-2-0028 and by the Delaware Sea Grant under Grant No. NOAA SG2016-18 R/RCE-9.

\section{REFERENCES}

[1] Figlus, J., Kobayashi, N., Gralher, C., and Iranzo, V. (2011). "Wave overtopping and overwash of dunes." J. Waterway, Port, Coastal, Ocean Eng., 10.1061/ASCEWW.1943-5460.0000060, 26-33.

[2] Garcia,R., and Kobayashi, N. (2015). "Trunk and head damage on a low-crested breakwater." J. Waterway, Port, Coastal, Ocean Eng., 10.1061/ (ASCE) WW. 1943-5460.0000276, 04014037.

[3] Irish, J.L., Lynett, P.J, Weiss, R., Smallegan, S.M., and Cheng, W. (2013). "Buried relic seawall mitigates Hurricane Sandy's impacts.” Coastal Eng., 80, 79-82.

[4] Walling,K., Miller, J.K., Herrington, T.O., and Eble, A. (2014). " Comparison of Hurricane Sandy impacts in three New Jersey coastal communities." Proc. 34th Coastal Eng. Conf., Management 38, 114. 